\title{
Pengembangan Strategi Literasi Keluarga Untuk Meningkatkan Minat Baca Anak Usia Dini \\ (Penelitian Pengembangan pada siswa kelompok B PAUD BAI Rumah Cendekia Kabupaten Bogor)
}

\author{
Nurdini Ferianti ${ }^{1}$ Irna $^{2}$ \\ STKIP Muhammad Bogor \\ 1dini.ferianti88.dk@gmail.com
}

DOI : $10.37329 /$ cetta.v3i1.415

\begin{tabular}{l}
\hline Keywords: \\
\hline Strategy Literacy \\
Of Family, \\
Reading Interest \\
OfChildhood \\
\hline
\end{tabular}

\begin{abstract}
This research has a purpose to increase the reading interest of childhood through literacy activities based on family. In fact, reading interest of childhood is still low. It's caused by low motivation of child in reading. The low stimulation of reading can obstruct development of chid language. One of strategies that can implemented to increase this reading interest in this research is Literacy activities based on family. This family literacy activities is given to children in their family. Research methode that's used in this research is Research and Development. This research consist of introduction, litercy strategic development based on family, validation of literacy strategies based on family, trials and revision of literacy strategies development based on family and the last is implementation of procedure of literacy sstrategies development based on family. Subyek of this research are students of class B in PAUD BAI Rumah Cendekia, in Bogor Disstrict. Result of this research is hoped can become on of alternatives of strategies in increasing the reading interest of childhood
\end{abstract}

\begin{tabular}{l}
\hline Kata Kunci: \\
\hline Strategi Literasi \\
Keluarga, Minat \\
Baca anak
\end{tabular}


Cendekia Kabupaten Bogor. Penelitian action research ini tediri dari empat komponen yaitu peerencanaan, tindakan, observasi dan refleksi. Analisis data yang digunakan yaitu kualitatif dan kuantitatif. Hasil dari penelitian ini diharapkkan dapat menjadi salah satu alternatif dalam meningkatkan minat baca pada anak usia dini. Adapun luaran dalam penelitian ini yaitu seminar nasional.

\section{Pendahuluan}

Anak usia dini yaitu anak yang berusia nol sampai delapan tahun. Hal ini sesuai dengan yang telah ditetapkan UNESCO bahwa rentang usia anak 0 - 8 tahun masih berada pada Early Childhood Education (Santoso, 2011). Usia ini merupakan fase yang fundamental bagi perkembangan individu. Usia ini juga disebut usia emas atau golden age. Golden age merupakan masa yang tepat untuk meletakkan dasar-dasar pengembangan kemampuan fisik, kognitif, bahasa, sosial, emosional, konsep diri, disiplin, kemandirian, seni, moral dan nilai-nilai agama. Pada masa ini otak anak mengalami perkembangan paling cepat sepanjang kehidupan. Menurut penelitian menunjukkan bahwa pada usia 8 tahun tingkat kecerdasan sudah mencapai 80\% (Anam, 2007). Usia dini merupakan masa penting bagi perkembangan potensi anak. Perkembangan kecerdasan anak memerlukan arahan yang baik dan benar salah satunya yaitu perkembangan bahasa.

Membaca merupakan salah satu aspek keterampilan dari empat aspek dalam berbahasa. Anak usia dini memerlukan banyak informasi untuk pengetahuannya agar siap menjadi manusia yang sesungguhnya. Dalam hal ini membaca merupakan cara untuk mendapatkan informasi karena pada saat membaca seluruh aspek kejiwaan manusia terlibat dan ikut serta terlibat. Menstimulasi minat baca anak lebih penting daripada mengajarkannya membaca. Menstimulasi memberikan efek yang menyenangkan. Pada anak kelompok B PAUD BAI Rumah Cendekia masih banyak anak yang belum memiliki minat membaca.

Berdasarkan uraian di atas, penelitian ini mengkaji terkait penerapan kegiatan literasi keluarga dalam meningkatkan minat baca anak usia dini. Adapun tuuan dari penelitian ini dantaranya untuk mengembangkan strategi pembelajaran literasi berbasis keluarga untuk meningkatkan minat baca anak di PAUD BAI Rumah Cendekia, untuk mengetahui langkah-langkah penggunaan strategi literasi berbasis keluarga di PAUD BAI Rumah Cendekia dan untuk mengetahui efektifitas pengembangan strategi literasi 
berbasis keluarga di PAUD BAI Rumah Cendekia. Literasi atau dalam bahasa Inggris literacy merupakan landasan untuk kegiatan belajar sepanjang hayat. Hal ini sangat penting untuk pembangunan sosial dan manusia demi meningkatkan kemampuan agar dapat merubah hidup ke arah yang lebih baik. Semula literasi hanya diartikan sebagai kemelek-hurufan. Namun hal ini merupakan persepsi yang salah. Mengartikan literasi sebagai kemelek-hurufan dapat berakibat pada terjadinya anomali melek huruf. Dimana yang dimaksudkan melek huruf adalah hanya berkisar pada kemampuan baca tulis secara harfiah dan teknis. Bukan secara budaya dan mendalam. Oleh karena itu literasi lebih sesuai diartikan sebagai keberaksaraan. Seperti halnya yang dikatakan oleh Irkham dalam (Gong, 2012) bahwa literasi adalah keberaksaraan.

Menurut Megawangi dalam Maryam (2002) keluarga adalah wahana untuk mendidik, mengasuh, dan mensosialisasikan anak, mengembangkan kemampuan seluruh anggotanya agar dapat menjalankan fungsinya dengan baik di masyarakat, serta memberikan kepuasan dan lingkugan yang sehat guna tercapainya keluarga sejahtera. Keluarga memiliki peranan yang luar biasa dalam perkembangan seseorang. Salah satu fungsi keluarga adalah fungsi edukatif. Keluarga merupakan wahana lingkungan pendidikan pertama dan utama bagi seseorang. Begitupun dnegan penumbuhan minat baca. Penumbuhan minat baca atau kegiatan membudayakan minat baca berawal dalam keluarga. Artinya Jika seorang anak lahir dan dibesarkan dalam keluarga yang suka membaca langsung, anak akan melihat dan merasakan bahwa kegiatan membaca merupakan kegiatan yang bermanfaat dan menyenangkan (Irsa Meilawati, 2015). Dari beberapa pendapat yang sudah dikemukakan di atas dapat kita simpulkan bahwa peran keluarga baik orang tua ataupun pengasuh anak sangat penting dalam pendidikan anak usia dini utamanya untuk membentuk budaya membaca. Keluarga memiliki peran dan kesempatan yang banyak untuk berinteraksi dengan anak-anaknya karena keluarga karrna keluarga adalah wahana pertama dan utama dalam pendidikan anak usia dini.

Bentuk-bentuk kegiatan literasi keluarga yang dilakukan adalah 1) parenting tentang menumbuhkan minat baca AUD dan teknik membacakan buku kepada anak, 2) orang tua membacakan buku di rumah, 3) orang tua membacakan buku di satuan PAUD, 4) home visit, 5) membuat pojok baca di rumah dan di sekolah, 6) berkunjung ke perpustakann, 7) berkunjung ke pameran buku, 8) membeli buku di toko buku, 9) mempublikasikan kegiatan di grup WA sekolah, 10) melakukan evaluasi kegiatan. 


\section{Metode}

Penelitian ini menggunakan pendekatan mix methods yaitu metode deskriptif, evaluatif dan eksperimen. Metode deskriptif digunakan untuk menghimpun data awal dalam analisis kebutuhan. Metode evaluatif digunakan dalam melakukan expert atau ahli dalam pengembangan suatu produk. Sedangkan eksperimen digunakan untuk mengetahui efektifitas pada uji untuk memastikan keberfungsian model yang dikembangkan.

Penelitian ini akan dilakukan dalam beberapa tahapan 1) Studi Pendahuluan/ persiapan dan pengumpulan data. Peneliti mencari informasi beserta data yang berkaitan dengan penelitian yang akan dilakukan. Kajian literatur tentang konsep anak usia dini, konsep minat baca anakserta hasil penelitian yang berkaitan dengan minat baca anak. Assesmen awal dilakukan untuk memperoleh gambaran singkat tentang minat baca anak dan penerapan strategi literasi berbasis keluarga untuk meningkatkan minat baca anak. Teknik yang digunakan dalam assesmen awal ini yaitu angket yang dilengkapi dengan hasil wawancara dan dokumentasi.

Pada studi pendahuluan ini dilakukan observasi untuk mengetahui pelaksanaan pengembangan minat baca anak secara langsung di sekolah. Dari observasi tersebut didapatkan (1) sarana dan prasarana yang digunakan guru dalam proses pembelajaran membaca (2) motivasi, sikap anak alam membaca (3) media, sumber belajar yang digunakan anak dan guru. Selanjutnya yaitu wawancara yang dilakukan oleh peneliti. Hal ini dilakukan untuk melengkapi secara langsung data peneliti berdasarkan keterangan guru, orang tua, kepala sekolah dan anak. Wawancara terhadap guru utuk mengetahui proses pembelajaran khususnya dalam bahasa yang selama ini dilakukan guru dalam hal strategi, pendekatan, metode dan kendala yang dihadapi. Wawancara pada siswa untuk mengetahui motIvasi siswa dalam membaca, 2) Pengembangan Design Strategi (a) kemampuan anak dalam membaca meningkat (b) setelah megikuti kegiatan anak akan merasa membaca itu menyenangkan (c) setelah mengikuti kegiatan anak mulai membaca buku dengan bahasanya sendiri, 3) Validasi Design rancangan awal model dilakukan oleh ahli yang berkompeten dibidangnya mengenai kelayakan produk yang akan dikembangkan, 4) Uji Coba Design produk yang dikembangkan untuk melihat apakah sesuai atau tidak dengan kondisi terkini, 5) Revisi Design kelemahan atau kekurangan dalam design diperbaiki agar design lebih sempurna dan dapat diimplementasikan, 6) Desimilasi dan Implementasi disampaikan pada pengguna melalui forum pertemuan agar dapat digunakan secara optimal. 


\section{Hasil Dan Pembahasan}

\section{Uji Coba Design Model Strategi Literasi Berbasi Keluarga}

Uji coba design model strategi literasi berbasi keluarga ini dilakukan untuk melihat kelayakan model strategi setelah dilakukannya revisi oleh para ahli. Uji coba design ini dilakukan di sekolah PAUD BAI Rumah Cendekia dan juga di rumah. Disini pihak sekolah hanya sebagai fasilitator, peran penting dilakukan oleh orang tua dan anak. PAUD BAI Rumah Cendekia memiliki 38 siswa yaitu 22 siswa kelas B (5 - 6 tahun), 11 siswa kelas A (4 - 5 tahun) dan Play Grup 5 siswa (3 - 4 tahun). Pada uji coba ini terdapat beberapa revisi dari para ahli terkait model strategi pengembangan literasi berbasis keluarga.revisi tersebut berupa tata letak tahapan yang akan dilakukan.

Pada pengembangan model design draft 2 dilakukan setelah uji coba model design draft 1 guna melihat apakah model design draft 2 ini juga mendapatkan revisi dari para ahli. Pada moel draft 1 dan draft 2 tetap menggunakan bagan untuk menggambarkan proses dan langkah-langkah penerapan strategi literasi keluarga terhadap minat baca anak secara berurutan. Terdapat beberapa komponen tambahan dalam langkah tahapan penerapan strategi yaitu adanya kegiatan parenting dan kegiatan orang tua membacakan buku di sekolahuntuk lebih jelasnya dapat dilihat pada bagan di bawah ini setelah revisi

Setelah melakukan assesmen awal, peneliti selanjutnya menyusun langkah penerapan strategi literasi keluarga diantaranya: (a) Parenting dilakukan untuk memperkenalkan kepada orangtua tentang kegiatan literasi keluarga untuk menumbuhkan minat baca anak dan teknik membacakan buku kepada anak, (b) Orang tua membacakan buku di rumah, setelah orang tua mendapatkan materi parenting dari pihak sekolah, orang tua diminta untuk mengajak anak membaca buku di rumah, (c) Orang tua membacakan buku di satuan PAUD, pada hari yang telah ditentukan semua orang tua siswa diundang untuk hadir di sekolah dalam kegiatan membacakan buku pada anak. Di sini peneliti dan pihak sekolah akan melihat antusias orang tua dan anak. (d) Berkunjung ke perpustakan, selanjutnya pihak sekolah mengatur jadwal untuk melakukan kunjungan ke perpustakaan bersama siswa. (e) Berkunjung ke pameran buku, orang tua memberikan informasi pada pihak sekolah telah mengajak anaknya pergi ke pameran buku, hal ini diinformasikan melalui grup Whatsapp. (f) Membuat pojok baca di rumah pihak sekolah memberkikan informasi pada semua orang tua siswa bahwa akan mengadakan lomba membuat pojok baca di rumah. Hal ini diinformasikan pada saat kegiatan parenting. (g) Membeli buku di toko buku, para orang tua akan diminta untuk 
mengajak anak pergi ke toko buku memilih buku bacaan yang disukai anak. (h) Home Visit, dilakukan oleh pihak sekolah mengunjungi satu persatu rumah siswa untuk melihat hasil kerja anak bersama orang tuanya dalam membuat dan menghias pojok baca di rumahnya

Model final ini merupakan model akhir yang telah dirancang berdasarkan revisi dari model draft yang ke 2. Pada model draft ke 2 ini tidak banyak mendapatkan perubahan dari para ahli karena dianggap final.

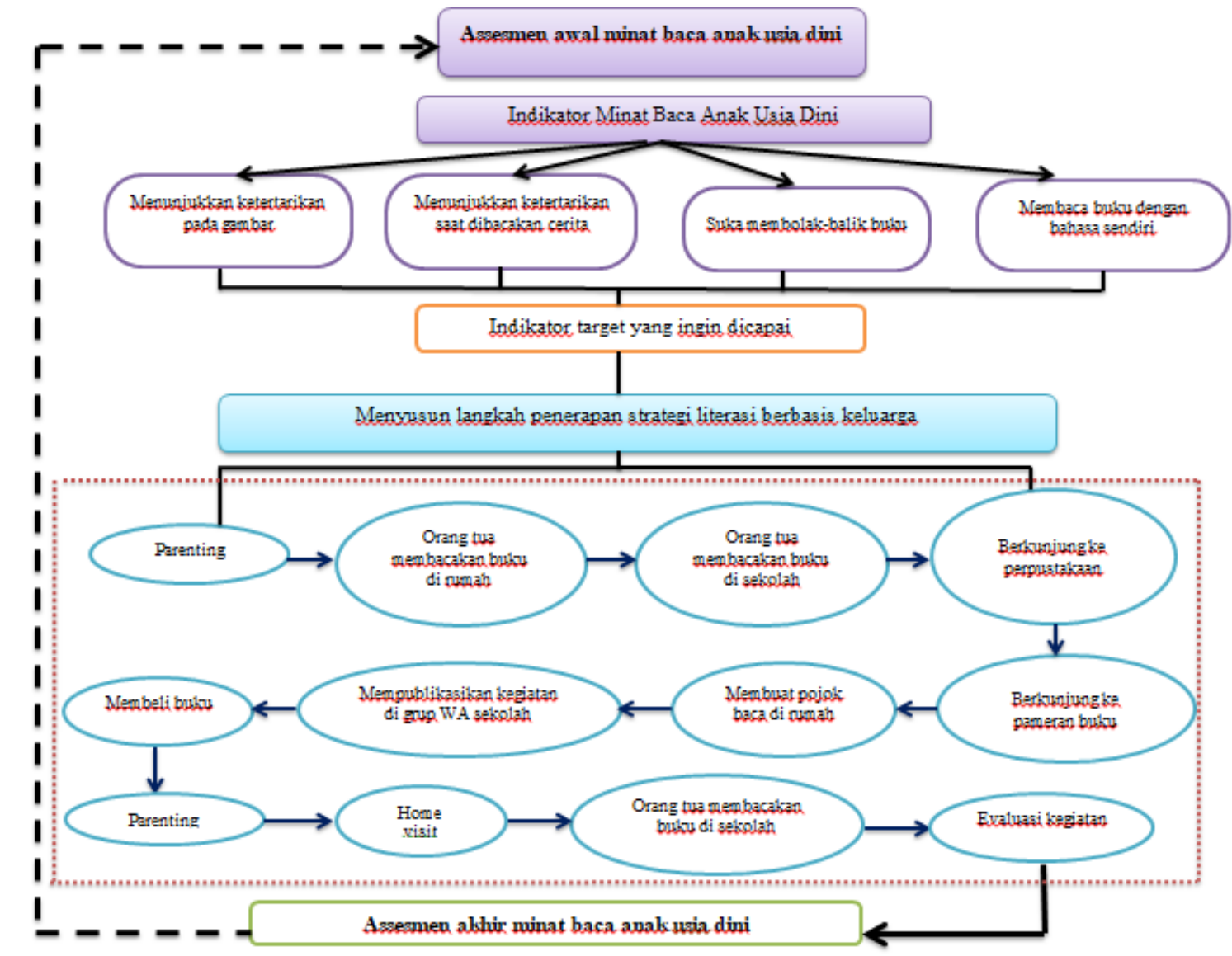

\section{Uji Efektivitas di PAUD BAI Rumah Cendekia}

Uji efektvitas ini dilakukan di PAUD BAI Rumah Cendekia kecamatan Ciomas dengan jumlah anak yaitu 22 anak. Hasil assesmen dijelaskan pada table di bawah ini:

Tabel 1 Nilai Pre Tes dan Post Tes Minat Baca Anak PAUD BAI Rumah Cendekia

\begin{tabular}{|c|c|c|c|}
\hline No & Nama anak & Pre Test & Post Test \\
\hline 1 & AK & 17 & 27 \\
\hline 2 & MZ & 16 & 27 \\
\hline 3 & DA & 17 & 28 \\
\hline 4 & YS & 15 & 27 \\
\hline 5 & MFB & 14 & 29 \\
\hline
\end{tabular}




\begin{tabular}{|c|c|c|c|}
\hline 6 & MN & 17 & 28 \\
\hline 7 & ZP & 17 & 29 \\
\hline 8 & RA & 17 & 26 \\
\hline 9 & AA & 15 & 26 \\
\hline 10 & MA & 14 & 26 \\
\hline 11 & KSR & 15 & 27 \\
\hline 12 & MA & 17 & 27 \\
\hline 13 & AH & 16 & 29 \\
\hline 14 & DU & 16 & 27 \\
\hline 15 & AF & 16 & 26 \\
\hline 16 & HA & 15 & 26 \\
\hline 17 & KA & 14 & 26 \\
\hline 18 & NA & 14 & 26 \\
\hline 19 & RN & 16 & 26 \\
\hline 20 & SA & 15 & 26 \\
\hline 21 & MD & 15 & 26 \\
\hline 22 & MZ & 16 & 26 \\
\hline 10 & MA & 16 & 26 \\
\hline
\end{tabular}

Dilihat dari hasil pre test dan post tes pada table di atas dapat disimpulkan bahwa penggunan strategi literasi keluarga dapat membantu meningktkan minat baca pada anak di kelompok B PAUD BAI Rumah Cendekia. Untuk lebih jelasnya dapat dilihat pada gambar di bawah ini:

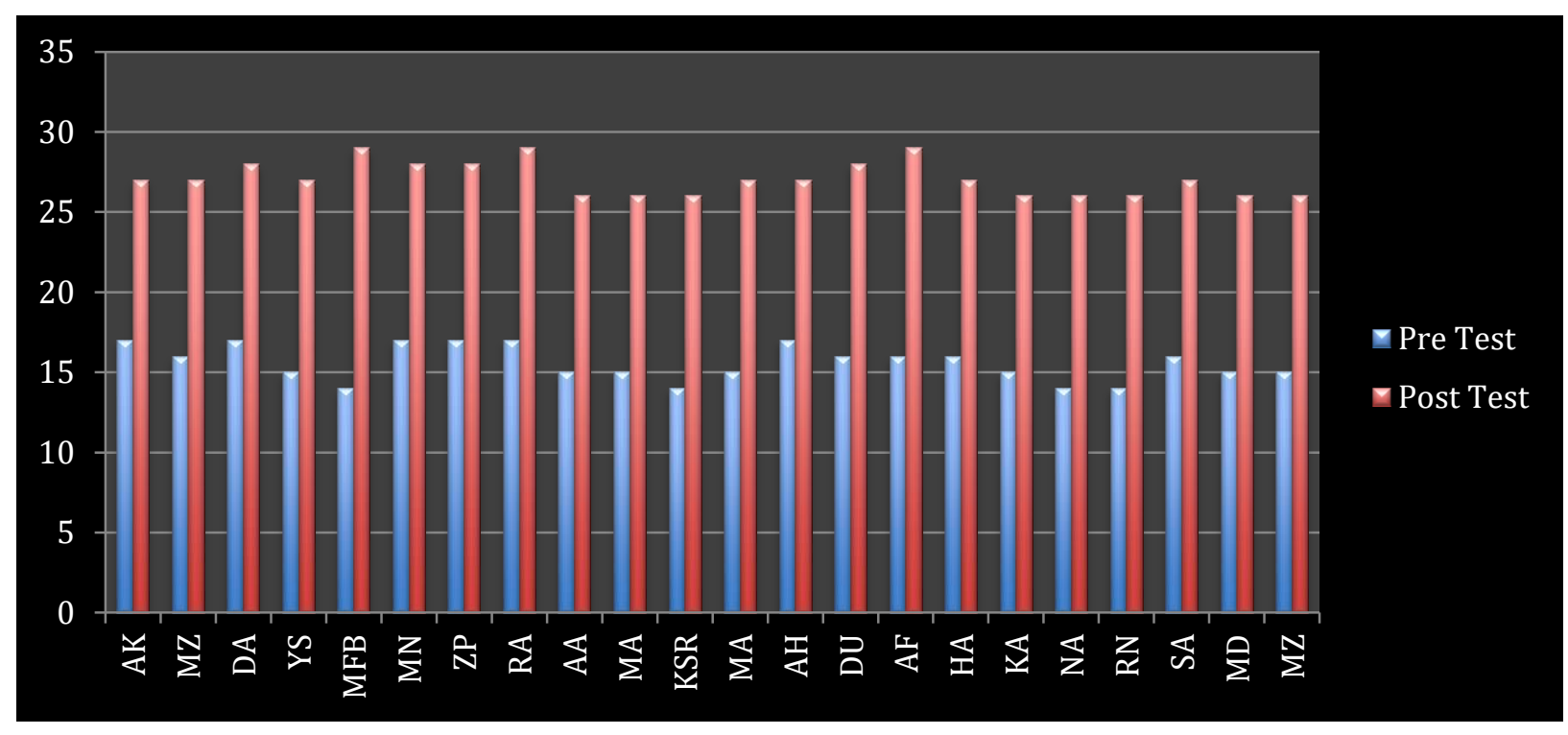

Gambar 1 Diagram batang peningkatan minat baca anak 
Perkembangan pesat dibidang pendidikan anak usia dini dilandasi oleh enam aspek perkembangan diantaranya perkembangan agama dan moral, perkembangan fisik motorik, perkembangan kognitif, perkembangan bahasa, perkembangan sosial emosional dan perkembangan seni. Perkembangan bahasa menjadi salah satu aspek penting karena bahasa adalah kunci untuk berkomunikasi dengan lingkungan dan mengekspresikan pikirannya Perkembangan bahasa dibagi menjadi empat yaitu keterampilan mendengar, keterampilan berbicara, keterampilan membaca dan keterampilan menulis.

Membaca merupakan salah satu aspek keterampilan dari empat aspek dalam berbahasa. Anak usia dini memerlukan banyak informasi untuk pengetahuannya agar siap menjadi manusia yang sesungguhnya. Dalam hal ini membaca merupakan cara untuk mendapatkan informasi karena pada saat membaca seluruh aspek kejiwaan manusia terlibat dan ikut serta terlibat. Pada keterampilan membaca anak usia dini saat proses pembelajaran membaca secara formal belum dilaksanakan. Yang dilakukan lembaga adalah pengembangan keterampilan agar anak tersebut siap untuk belajar membaca, seperti membaca gambar.

Kegiatan pembelajaran yang berlangsung selama ini cenderung hanya sebatas memenuhi kurikulum bukan memenuhi kebutuhan dan kepentingan anak. Banyak sekolah-sekolah yang fokus mengajarkan anak untuk membaca dan orang tua juga banyak memasukkan anak mereka ke sekolah-sekolah yang benar-benar mengajarkan anak membaca. Permasalahan pembelajaran bahasa (membaca) berdampak pada anak didik. Berdasarkan hasil observasi ditemukan beberapa permasalahan seperti anak didik merasa bosan saat mengikuti keiatan pembelajaran karena belum adanya ketertarikan anak dalam membaca, anak didik juga hanya mendengarkan penjelasan guru atau mendengarkan cerita yang dibacakan guru saja tanpa adanya respon ketertarikan dari anak

Menstimulasi minat baca anak lebih penting daripada mengajarkannya membaca. Menstimulasi memberikan efek yang menyenangkan. Selama ini kegiatan membaca selalu bersumber dari guru-guru yaitu belum adanya kemauan dari anak untuk memulai membaca. Pengembangan strategi literasi keluarga ini merupakan model yang didasarkan atas kerjasama antara pihak orang tua dan sekolah. Dengan demikian orang tua akan diikutsertakan dalam kegiatan pembelajaran untuk meningkatkan minat baca anak. 
Sebagaimana telah diketahui bahwa model pembelajaran merupakan cara memuat pola atau merancang suatu pembelajaran yang diterapkan pada pembelajaran sesuai dengan tujuan belajar. Dengan demikian strategi literasi keluarga ini sangat cocok dengan karakteristik anak dalam menumbuhkan minat baca. Dengan memperhatikan relevansi pada model yang akan dikembangkan dalam penelitian ini, maka dapat dikemukakan kerangka kerja modepembelajaran menumuhkan minat baca anak melalui strategi literasi keluarga diantaranya : 1) identifikasi dan analisis kebutuhan, 2) analisis pengembangan strategi literasi keluarga, 3) pengembangan model strategi literasi keluarga, 4) ujicoba draft 1,5) revisi model (uji pakar), 6) uji coba model draft 2,7) model final.

Setelah melalui proses panjang dalam megembangkan model strategi literasi keluarga untuk meningkatkan minat baca anak, peneliti berharap srategi ini berguna sebagai salah satu solusi membantu guru maupun sekolah dalam meningkatkan minat baca anak usia dini.

\section{Kesimpulan}

Berdasarkan penelitian yang telah dilakukan dapat diketahui bahwa strategi literasi keluarga dapat meningkatkan minat baca anak di PAUD BAI Rumah Cendekia. Hal ini terlihat dari hasil akhir yaitu pre test dan post test minat baca anak serta hasil wawancara akhir yang dilakukan pada orang tua anak dan guru serta minat baca anak yang meningkat setelah dilakukan strategi ini. Dengan diterapkannya strategi ini minat baca anak meningkat dan kemampuan membaca anakpun berkembang. Validasi dari para pakar terhadap strategi yang dikembangkan sudah memenuhi kriteria yang layak dalam meningkatkan minat baca anak. Strategi literasi keluarga bisa menjadi salah satu pilihan alternatif dalam meningkatkan minat baca anak usia dini.

\section{Daftar Pustaka}

Anam, S. (2007). Taman yang Paling Indah. Solo: PT Jangsa Watra Lestari.

Handini, M. C. (2012). Metodologi Penelitian untuk Pemula. Jakarta: FIP Press.

Kementerian Pendidikan dan Kebudayaan. (2017). Literasi Baca Tulis, Gerakan Literasi Nasional. Jakarta.

Meilawati, I. (2015). Pengaruh Literasi Keluarga Terhadap Minat Baca Dan Kemampuan Literasi Dini Siswa Kelas Awal. Universitas Pendidikan Indonesia | repository.upi.edu | perpustakaan.upi.edu). 
Santoso, S. (2011). Konsep Pendidikan Anak Usia Dini Menurut Pendirinya 2. Jakarta: Universitas Negeri Jakarta.

Sukardi. (2003). Metodologi Penelitian Pendidikan: Kompetensi dan Praktiknya Yogyakarta: Bumi Aksara, 2003.

Uno, H. B., Lamatenggo, N. \& Koni, S. (2011). Menjadi Peneliti PTK yang Profesional. Jakarta: PT Bumi Aksara. 